\title{
A short history of engineering geology and geophysics at the British Geological Survey
}

\author{
M G Culshaw ${ }^{1}$, K J Northmore ${ }^{2}$ \& D M McCann²
}

\author{
${ }^{1}$ British Geological Survey, Keyworth, Nottingham, NG12 5GG, UK and School of Civil \\ Engineering, University of Birmingham, Edgbaston, Birmingham, B15 2TT, UK \\ (martin.culshaw2@ntlworld.com +44(0)115911 9137) \\ ${ }^{2}$ formerly British Geological Survey, Keyworth, Nottingham, NG12 5GG, UK \\ (kevin.northmore@ tiscali.co.uk +44(0)115 923 1638; dmccann2@btinternet.com)
}

\begin{abstract}
Engineering geology in the British Geological Survey (BGS) began, in a formal sense, with the creation of the Engineering Geology Unit in 1967. Virtually since its inception, despite changing research priorities and economic drivers, the survey and research work carried out by BGS engineering geologists can be conveniently divided into four broad research areas: engineering geological mapping and urban geoscience, geotechnical properties of soils and rocks, engineering geophysics and geohazards. Since the late 1960s engineering geologists have undertaken innovative research initiatives and continue to play an important role in ensuring the delivery of BGS research.
\end{abstract}

Keywords: History of engineering geology, British Geological Survey

\section{In the Beginning}

Engineering geology in the British Geological Survey began, formally, in 1967 with the creation of the Engineering Geology Unit (EGU) (a name that changed many times over the next 45 years) under the leadership of Roger Cratchley (a geophysicist with a civil engineering degree). It followed the formation of the Natural Environment Research Council (NERC) in 1965 and the merging of the Geological Survey of Great Britain (GSGB) with the Overseas Geological Survey (OGS) to form the Institute of Geological Sciences (IGS), which was a research institute within the NERC, as well as the national Geological Survey (later to be renamed the British Geological Survey [BGS] in 1984). Based in the IGS London office, the Unit was formed at a time when engineering geology in the UK was gaining increasing recognition as an important sub-discipline of geology. This was reflected by the establishment of five Master of Science postgraduate courses in engineering geology in the 1960s and 1970s and by the formation in 1964 of the Engineering Group of the Geological Society (later incorporating the International Association of Engineering Geology UK National Group). 
The Chief Geophysicist of the IGS at the time was instrumental in setting up the Engineering Geology Unit, almost certainly taking the view that it would act as a physical properties laboratory to provide fundamental data for the Geophysics Division. However, Roger Cratchley saw the EGU as developing into a more inclusive research laboratory involving site investigation including the drilling and sampling of boreholes, undertaking a wide range of soils and rock mechanics tests and geohazard (particularly landslide) studies. He was also interested in rock mass assessment using geophysical methods and the stability of major rock formations. As a consequence, Roger Cratchley was responsible for broadening the initial remit of the Unit to encompass both engineering geology and what came to be known as engineering geophysics - a remit that carries through to the present day.

The EGU was formed at a time when the traditional geological field mapping units were viewed as the 'flagship' of the IGS. Almost without exception these units were opposed to the formation of an engineering geological group that they perceived would impinge on their areas of work. Indeed, this opposition resulted in the EGU being excluded from the general IGS national mapping programme which, with the singular exception of a geological and geotechnical study of south-east Essex in the early-mid 1970s, lasted until a programme of government-funded applied mapping projects were commissioned in the 1980s.

From a complement of three staff in 1967 the Unit expanded rapidly, recruiting both experienced researchers and a number of young geologists, geophysicists and engineering geologists (including graduates from the relatively new MSc courses). By the mid 1970s the Unit's complement stood at around 20. Today, the number of engineering geologists and geophysicists is still around this number. A key factor in the role of the group was that from its creation the EGU provided a unique capability that combined geology and soil and rock mechanics with geophysics - a multidisciplinary approach that continues to be the hallmark of the Unit's research programme.

\section{Early Research (1967 - 1970s)}

Early progress in setting up the fledgling EGU was impressive, and included the commissioning, in 1971, of a rock and soil mechanics, geophysical properties and electronics laboratory complex to underpin research programmes. Early EGU research initiatives were essentially developed by the senior Unit staff, largely reflecting their basic research interests. These included four main areas: engineering geological mapping, geotechnical/geophysical property determinations, slope stability studies and research into the application of geophysical methods to engineering. 
In 1968/69, following consultations with John Knill at Imperial College London, an initial research programme was begun that included the engineering geological mapping of an area designated for the new town of Milton Keynes, some $80 \mathrm{~km}$ north west of London, mapping and process studies of active landslide areas on the Dorset coast (200 km south west of London) and investigating the geotechnical and geophysical properties of Jurassic strata based on sampling and testing a range of lithologies from the Dorset to Yorkshire outcrop that trends north-east south-west across central England. Further innovative studies involved near-shore lithological/engineering geological mapping of the western part of Lyme Bay, Dorset to about $3 \mathrm{~km}$ offshore. This latter study resulted in a marine geological map linking the onshore and offshore geology - the only one of its kind produced by the BGS. Such sea floor studies also spurred early work into developing geophysical seabed tools to acquire geophysical property data of offshore sediments.

The Milton Keynes engineering geological mapping project provided valuable experience and lessons for future similar studies. Importantly, the study enabled EGU to develop the principles on which later engineering geological maps were produced and highlighted the need for good subsurface data.

\section{The Rothschild Years (1970s -1980s)}

In 1972, publication of the Government's Rothschild Report into the funding of science in British research centres and surveys was of great significance to BGS. This report recommended that approximately $30 \%$ of the core funds be transferred to central government departments, which would then 'commission' work back from them. Previously, the amount of applied geological mapping carried out by the BGS had been minimal with most mapping being of the traditional litho-stratigraphical type. However, in 1972 the Department of the Environment (DoE) commissioned the geological and geotechnical study of the site and $450 \mathrm{~km}^{2}$ hinterland of the then proposed third London airport in south east Essex (around $70 \mathrm{~km}$ east of London). This was a significant milestone for engineering geology mapping and the provision of applied geological data in general. The south east Essex work was completed in 1977 and published as a twelve part report with a wallet of over 50 maps. This was IGS's first truly multidisciplinary project involving input from a wide spectrum of IGS expertise. The study utilized a range of techniques to acquire subsurface data, including continuous seismic profiling along river channels to ascertain the presence and distribution of buried channels. It provided the opportunity to experiment with different ways of presenting the three dimensional geology, with emphasis on the variations in lithological and physical/geotechnical characteristics of the sediments and sedimentary rocks of the area. Also, it allowed novel presentation of geohazard data (particularly related to collapsible loessic de- 
posits and landslides). Significantly, it gave rise to the setting up of a major borehole and geotechnical property database from existing and new boreholes.

Further government contracts included a major study to map and classify landslides in the South Wales Coalfield region (about $250 \mathrm{~km}$ west of London) resulting in a landslide database and a series of maps locating and classifying nearly 580 landslides, a regional assessment of foundation conditions for industrial development in the Forth and Cromarty Firth Estuaries in eastern Scotland resulting in geotechnical profile maps classified in terms of bearing capacity and settlement data and geophysical research into indirect methods of assessing ground conditions for civil engineering purposes - particularly cavity location.

Other commissioned research during this period included a major geotechnicalstudy to assess soft, seafloor sediments in the North Sea and identify potential hazards (for example, gas-containing soft clay-silts, 'pockmarks', soft infilled channel deposits, mobile sand waves and foundered strata) that may affect the stability of oil production platforms and pipeline trenches. The work highlighted the technical difficulty and cost of acquiring sediment data and suitable 'undisturbed' samples and led to a further research programme, in collaboration with others such as the Marine Science Laboratory, University College of North Wales, to find methods of indirectly determining properties of rocks and sediments by geophysical methods.

A key aspect of the EGU work at this time was the provision of reports, maps and data aimed to meet the needs of planners. This was enhanced by the increased communication between geotechnical engineers and engineering geologists that was fostered, in no small part, by the Engineering Group of the Geological Society and its journal (the Quarterly Journal of Engineering Geology), particularly its efforts to promote standardization of terminologies, rock and soil classifications and preparation of maps and plans for engineering and planning purposes. Against this background, the EGU tended to concentrate on the strategic approach to regional problems and so concerned itself with regional studies of ground conditions in new urban developments and landslide surveys and stability analyses, both for planning purposes and to guide the subsequent site investigation for design.

\section{The requirement for national data sets $(1980 \mathrm{~s}-2005)$}

In the early 1980s a review of government expenditure and priorities heralded a new era of 'Commissioned Research' in which the contracts were no longer allocated as part of a 'rolling programme' but mainly won competitively. From about 1980 till 1996, the DoE (it had many different names during the period but the key point was that it was responsible for land-use planning policy) funded a series of 
more than 60 studies of the applied geology/environmental geology of British urban areas (Brook and Marker 1987). For each area a report and a series of maps were produced. Not all the projects were led by BGS but of those that were, the engineering geologists had a significant input to most of them.

A parallel EGU research programme into the engineering geology of major UK formations such as the Gault Clay and Mercia Mudstone Group (later to include Lias and Lambeth Group strata) formed a major underpinning to the overall research programme. This somewhat unglamorous research resulted in a series of technical reports that are freely available on-line. It is interesting to note that the report on the Mercia Mudstone Group is the most downloaded of all the reports and publications in external scientific journals produced by the whole of NERC!

Through the applied mapping projects, a huge amount of geotechnical data was being acquired and entered into project-specific databases on desk-top computers (PC's). However, with improvement in computing power and software, a corporate approach was adopted. In 1992-3 efforts were directed to bring together and validate the 'local' databases and develop a single geotechnical database design. This was the beginning of the corporate 'National Geotechnical Properties Database,' which currently contains $250000+$ property values from over 63000 boreholes. A landslide database created for an applied mapping study of Bradford formed the basis for the creation of the corporate National Landslide Database that followed some years later. A karst database has also been developed and populated. These databases formed the basis for the provision of national property and geohazard data sets which, in the late 1990s, were commercially licensed with other digital BGS information and become an important source of BGS income.

Of particular significance was the creation, in 1992, of a digital, national geohazard assessment tool (GHASP - GeoHAzard Susceptibility Package), for the UK insurance industry. This followed a period of exceptionally dry weather in 198990 in south east of England, which led to some $£ 1$ bn of insurance claims for damage to house foundations caused by shrinkage of mainly Mesozoic and Tertiary clay formations, often rich in montmorillonite. The development of the assessment tool required the digitisation of Britain's geological maps, initially, as raster scans. In the early 2000s, a tax windfall allowed the BGS to vectorise all its 1:50 000 scale geological maps (DiGMap50) (and other data) and develop a new geohazard susceptibility assessment system called GEOSURE that continues today.

\section{Overseas Research Collaborations}

From its early years the EGU undertook many engineering geological assignments around the world, funded largely through the then Overseas Development Admin- 
istration's Research and Development and Knowledge Transfer Programmes but, also, through winning commercial contracts, occasionally in collaboration with private consultancies. The work mirrored the EGU's UK research areas.

\section{Engineering Geology and 3D modeling (2005 - Present)}

From about 2005, emphasis became directed towards creating 3D digital models and new research in urban areas is now firmly, but not exclusively, based around 3D modeling. Development of a national 3D digital geological model and the property attribution of that model is now a major thrust of BGS research.

2006 saw the start of a 'ramping down' of BGS's 'National Capability' funding, reducing many of its core activities. Also, emphasis has swung towards a regime of competitively won, externally-funded research, rather than 'relatively routine,' though important, commercial commissions. However, new drivers and research directions notwithstanding, the long-term nature of much of the engineering geological work (not least, the effects of climate change on geotechnical behaviour and geohazard risk) means that many of the intentions of the original EGU remain. Under the 2013 operational structure, the EGU research areas still endure as Urban Geoscience, Geotechnical and Geophysical Properties and Processes, Geophysical Tomography, and Shallow Geohazards and Risks within the BGS Geohazards Programme. Better knowledge of the disposition of geological formations, their properties and how they are influenced by natural/anthropogenic processes remain permanent requirements for users of engineering geological information.

Acknowledgments: This paper is published with the permission of the Executive Director of the British Geological Survey (NERC). The comments of Stuart Duncan are gratefully acknowledged.

\section{References}

Information, in the form of BGS maps, reports and external publications, is available for all the project studies referred to in this paper through the BGS library, the NERC Open Research Archive (NORA - www.nora.nerc.ac.uk) and the BGS website (www.bgs.ac.uk).

Brook, D. and Marker, B. R. 1987. Thematic geological mapping as an essential tool in land-use planning. In: "Planning and Engineering Geology," Engineering Geology Special Publication No. 4, Editors: Culshaw, M. G., Bell, F. G., Cripps, J. C. \& O'Hara, M. Geological Society, London. 211-214. 